\title{
PENGARUH PENAMBAHAN POLIFOSFAT DAN NATRIUM KLORIDA TERHADAP PENINGKATAN DAYA IKAT AIR UDANG PUTIH BEKU DAN EFISIENSI PROSES
}

\author{
[Influence of Polyphosphate and Sodium Chloride Addition on The Water Holding Capacity \\ of Frozen White Shrimp and Process Efficiency]
}

\author{
Azis Boing Sitanggang ${ }^{1,2 *}$, Andrian Teguh ${ }^{1}$, dan Adil Basuki Ahza ${ }^{1,2}$ \\ 1) Departemen IImu dan Teknologi Pangan, Fakultas Teknologi Pertanian, Institut Pertanian Bogor, Bogor \\ ${ }^{2)}$ Southeast Asian Food and Agricultural Science and Technology (SEAFAST) Center, Institut Pertanian Bogor, Bogor
}

Diterima 30 Maret 2018 / Disetujui 28 Januari 2019

\begin{abstract}
White shrimp (Litopanaeus vannamei) is one of the most popular seafood commodities, therefore, it has considerable economic value. The aim of this study was to evaluate the effect of polyphosphate and sodium chloride addition in the soaking solution on the water holding capacity (WHC) of frozen white shrimp at a pilot scale (i.e. $12 \mathrm{~kg}$ ), production cost efficiency and its sensory acceptance. Various combinations of salt and phosphates concentration were evaluated to obtain the most optimum condition for increasing the frozen shrimp WHC while the final product phosphate residue did not exceed $0.5 \%$. The highest WHC was obtained by soaking the white shrimps in a solution containing $2.5 \%$ polyphosphate MTR $80-P$ and $1.0 \% \mathrm{NaCl}$. The phosphate residue concentration determined in the final product was about $0.27 \%$. The final product multisample difference test (rating test) also confirmed that this combination was not detrimental to the perception of the consumers. Moreover, the use of soaking condition reduced the production cost (based on the raw material costs) by $\mathrm{Rp} .4 .580,900 / 2.000 \mathrm{~kg}$ finished products or equals to Rp. $2.290 / \mathrm{kg}$ finished products. Conclusively, the addition of polyphosphate and salt in soaking solution at the optimum concentration increased the WHC of the frozen white shrimps, reduced production cost without changing the product sensory acceptance.
\end{abstract}

Keywords: frozen shrimp, polyphosphate, sodium chloride, water holding capacity, white shrimp

\begin{abstract}
ABSTRAK
Udang putih merupakan salah satu komoditas perikanan yang paling popular, sehingga memiliki nilai ekonomis yang tinggi. Tujuan dari penelitian ini adalah untuk mengevaluasi pengaruh penambahan poli fosfat dan garam natrium klorida pada peningkatan daya serap air udang putih (Litopanaeus vannamei) beku pada skala pilotplant $(\sim 12 \mathrm{~kg})$, dan efisiensi biaya produksi serta penerimaan sensori produk tersebut. Disamping kontrol, terdapat enam (6) kombinasi perlakuan yang dilakukan untuk mendapatkan kombinasi optimum larutan perendaman dalam menghasilkan nilai daya ikat air tertinggi, dan residu fosfat kurang dari $0,5 \%$. Kombinasi polifosfat MTR $80-\mathrm{P}$ sebesar 2,5\% dan $\mathrm{NaCl} 1,0 \%$ memberikan nilai WHC tertinggi. Konsentrasi residu fos fat pada produk akhir didapatkan sebesar 0,27\%, dimana nilai ini jauh di bawah nilai ambang batas yang ditetapkan oleh Codex. Analisis sensori produk akhir berupa uji rating menunjukkan bahwa udang yang sebelumnya direndam dengan perlakuan terbaik di atas dapat diterima secara baik oleh konsumen. Selain itu, pada perlakuan ini didapatkan penghematan biaya produksi sebesar Rp. 4.580,900/2.000 kg produk jadi atau sebesar Rp. 2.290/kg produk jadi. Penelitian yang telah dilakukan menunjukkan bahwa dengan mengkombinasikan polifosfat dan garam pada konsentrasi optimum selama perendaman udang dapat meningkatkan daya ikat air, menurunkan biaya produksi tanpa mengubah penerimaan sensori produk tersebut.
\end{abstract}

Kata kunci: daya ikat air, natrium klorida, polifosfat, udang beku, udang putih

\section{PENDAHULUAN}

Udang merupakan salah satu komoditas perikanan yang paling banyak diekspor ke pasar inter-

*Penulis Korespondensi:

E-mail: boing.lipan@apps.ipb.ac.id nasional. Menurut data dari Kementerian Kelautan dan Perikanan (2015), angka ekspor udang dari Indonesia mencapai 162,580 ton pada tahun 2015. Selain itu, data yang diperoleh juga menunjukkan bahwa udang adalah salah satu komoditas yang mengalami kenaikan nilai ekspor yang tinggi pada tahun 2013-2014 yaitu sebesar 27,12\%. Menurut 
Codex, udang beku adalah produk dari udang segar yang sudah mengalami perlakuan pencucian dengan atau tanpa perlakuan pemotongan kepala, dan pembekuan hingga suhu pusat mencapai $-18^{\circ} \mathrm{C}$ atau lebih rendah (CAC, 1995). Udang yang digunakan juga harus udang segar hasil budidaya yang tidak berasal dari perairan tercemar dan boleh dengan atau tanpa kepala (BSN, 2014).

Tingginya angka perdagangan (ekspor) dari udang disebabkan oleh nilai gizi dari udang yang cukup tinggi. Kandungan protein yang terdapat pada udang berkisar $19-20 \%$ dan kandungan lemak berkisar 1,20-1,30\% (Puga-lopez et al., 2013). Komponen lemak yang dominan pada udang adalah fosfolipid, khususnya fosfatidilkolin dan sterol (Thepnuan et al., 2009). Udang juga kaya akan asam lemak tak jenuh esensial seperti eikosaheksanoat dan dokosaheksanoat yang bermanfaat bagi kesehatan (Chen et al., 2015). Konsentrasi terbesar dari lemak pada udang terdapat di bawah kulit udang. Oleh sebab itu, udang sangat rentan terhadap oksidasi lemak yang kemudian dapat menyebabkan timbulnya offflavor pada saat proses pengupasan kulit. Off-flavor yang muncul pada tahap ini akan tetap tertinggal pada produk akhir (Zhou et al., 2015).

Dalam proses penyimpanannya, udang harus terhindar dari stress, dan suhu di inti udang harus berada di bawah $0^{\circ} \mathrm{C}$ (Sriket et al., 2010). Pada suhu $-5^{\circ} \mathrm{C}$, udang dapat bertahan hingga $45-50$ hari berdasarkan parameter mutu kritis nilai total nitrogen volatil maupun berdasarkan skor penerimaan sensori (Tsironi et al., 2009). Stres pada udang saat penyimpanan akan berpengaruh pada munculnya bintik hitam dari melanosis pada tubuh udang. Melanosis dihasilkan oleh enzim polifenoloksidase yang mengoksidasi fenol menjadi kuinon (Nirmal dan Benjakul, 2010). Selain itu, stres juga dapat memengaruhi water holding capacity dan tekstur dari udang karena stres memengaruhi tingkat oksigen yang terlarut. Tingkat oksigen terlarut yang rendah menyebabkan glikolisis anaerobik terjadi. Peristiwa glikolisis anaerobik yang terjadi dapat menghasilkan asam laktat yang akan menumpuk di otot dan hemolimf (Soñanez-Organis et al., 2010). Disosiasi dari asam laktat akan menyebabkan turunnya $\mathrm{pH}$ jaringan mendekati titik isoelektrik miosin yaitu $5,4 / 5,5$ sehingga akan mengurangi kekuatan interaksi air dan protein serta juga menyebabkan terjadinya denaturasi miosin (Jantakoson et al., 2013).

Water holding capacity (WHC) atau kapasitas daya ikat air dapat didefinisikan sebagai sifat fisik dari makanan dan kemampuan dari struktur pangan untuk mencegah lepasnya air dari struktur tiga dimensional protein. WHC daging merupakan kemampuan dari daging untuk mengikat air dalam daging atau air yang ditambahkan selama adanya pemrosesan, misalnya pemanasan, penggilingan, pengadukan, dan tekanan (Hughes et al., 2014). WHC pa- da udang sendiri memengaruhi susut masak, tekstur, dan sensori, serta dengan tingginya WHC pada udang mampu meningkatkan umur simpan dari udang (Okpala, 2015).

Fosfat atau yang lebih dikenal sebagai garam dari asam fosfat adakah beberapa unit fosfat yang terhubung untuk membentuk struktur yang lebih kompleks, yaitu polifosfat. Fosfat memiliki struktur tetrahedral dimana empat atom oksigen terikat pada atom fosfor di tengah. Fosfat dibagi menjadi beberapa kategori tergantung pada panjangnya rantai fosfat, yaitu ortofosfat (satu grup fosfat), pirofosfat (dua grup fosfat), tripolifosfat (tiga grup fosfat), dan polifosfat (empat atau lebih grup fosfat). Untuk aplikasinya pada produk perikanan, kategori fosfat yang biasa digunakan adalah tripolifosfat dan polifosfat yang terbukti lebih efektif dalam peningkatan kualitas (Carneiro et al., 2012a).

Dengan struktur fosfat yang dapat mengikat empat atom oksigen sehingga mampu mengikat empat molekul air (melalui ikatan hydrogen), maka penambahan fosfat terhadap produk hasil laut termasuk udang dapat meningkatkan WHC dari produk terkait. Hal ini mengakibatkan produk dapat dijual pada bobot yang lebih tinggi, dan juga mencegah kehilangan bobot produk setelah proses thawing. Namun, apabila produk direndam pada larutan fosfat pada konsentrasi yang terlalu tinggi atau pada waktu yang terlalu lama, rasa menyerupai sabun akan timbul pada produk atau akan muncul lendir, dekomposisi dan translusens, sebagai akibat dari peningkatan $\mathrm{pH}$ (Gonçalves dan Ribeiro, 2008). Pada kasus lainnya, proteolisis dapat juga terjadi (Gonçalves dan Ribeiro, 2008). Penambahan fosfat dapat memengaruhi ionisasi dari molekul protein, dan interaksi antara molekul air dan protein, sehingga meningkatkan nilai $\mathrm{pH}$ dan kekuatan ionik. Peningkatan interaksi antara molekul air dan protein secara langsung akan meningkatkan WHC (Wachirasiri et al., 2013). Untuk menjaga kualitas udang, penambahan fosfat dirasa perlu, namun untuk menjaga tingginya konsentrasi fosfat pada produk akhir Codex membatasi nilai residu fosfat dalam bentuk $\mathrm{P}_{2} \mathrm{O}_{5}$ tidak boleh melebihi 1,0\% (CAC, 1995).

Penelitian yang dilakukan ini bertujuan menentukan kombinasi antara fosfat dan garam yang optimal untuk menaikkan kapasitas daya ikat air/WHC, dengan memperhatikan karakteristik sensori dari produk akhir udang beku. Disamping itu, penelitian ini juga bertujuan menentukan efektivitas dari penggunaan fosfat dalam hal pengurangan biaya produksi dari udang beku.

\section{BAHAN DAN METODE}

\section{Bahan}

Bahan baku yang digunakan adalah udang putih (Litopenaeus vannamei) PND (peeled, deveined, 
and tail-off), MTR 80-P (campuran sodium tripolifosfat, sodium polifosfat, sodium bikarbonat, garam, dan asam sitrat), MTR 79-N (campuran sodium bikarbonat, garam, dan asam sitrat), dan garam ( $\mathrm{NaCl})$. MTR 80-P, MTR 79-N, berasal dari Aura Barter Company, Ltd (Thailand), sementara garam klorida berasal dari Sigma-Aldrich (Singapura).

\section{Prosedur penelitian}

Penelitian dibagi menjadi dua bagian yaitu (i) bagian percobaan/trial perendaman dan (ii) pengujian. Uji organoleptik, residu $\mathrm{P}_{2} \mathrm{O}_{5}$, daya ikat air (water holding capacity) dan analisis biaya dilakukan setelah tahapan percobaan perendaman selesai dilakukan. Percobaan perendaman dilakukan dengan merendam sampel udang putih PND sebanyak tiga kali ulangan. Tahapan trial yang dilakukan menggunakan $12 \mathrm{~kg}$ udang PND untuk setiap perlakuan (tiga kali ulangan) dan setiap percobaan hanya dapat menguji dua perlakuan dan satu kontrol. Hal ini disebabkan oleh terbatasnya bahan baku dan faktor pendukung lainnya untuk melakukan pengujian sebanyak enam perlakuan dan satu kontrol secara bersamaan. Pada bagian ini, bahan yang digunakan adalah udang PND (peeled deveined and tail off) yang bagian kepalanya dibuang dan telah dilakukan proses pengupasan, pembelahan dan pembuangan usus. Udang direndam dengan rasio bahan dan larutan perendam (kombinasi garam, polifosfat dan sodium bikarbonat) 1:2 dengan kecepatan pengaduk sebesar $27 \mathrm{rpm}$. Perendaman dilanjutkan selama 18 jam pada suhu kurang dari $5^{\circ} \mathrm{C}$. Selanjutnya, udang ditiriskan, disusun pada rak untuk dibekukan. Untuk pengujian organoleptik, residu $\mathrm{P}_{2} \mathrm{O}_{5}$, daya ikat air menggunakan udang yang sudah dibekukan selama satu minggu, dan harus mengalami proses thawing menggunakan air dengan suhu $10-18^{\circ} \mathrm{C}$, lalu ditiriskan.

\section{Optimasi konsentrasi fosfat}

Sebelum proses perendaman (soaking) udang dimulai, larutan fosfat disiapkan dan dibagi menjadi control $(K)$ dan enam kondisi yaitu, A, B, C, D, E, dan $F$. Di dalam setiap perlakuan, pengukuran $K$ selalu dilakukan karena ketidakmungkinan untuk melakukan pengujian semua perlakuan pada hari yang sama, serta sulitnya memperoleh bahan baku dengan kualitas, kesegaran dan ukuran yang sama pada hari yang berbeda-beda. Kondisi A, B, dan C adalah larutan MTR 80-P dengan konsentrasi $2 \%$ dan dengan konsentrasi $\mathrm{NaCl}$ sebesar 0,$5 ; 1$ dan $2 \%$ berturut-turut. Kondisi $\mathrm{D}$, $\mathrm{E}$, dan $\mathrm{F}$ adalah larutan MTR 80-P dengan konsentrasi 2,5\% dengan konsentrasi $\mathrm{NaCl}$ sebesar 0,$5 ; 1$ dan $2 \%$ berturut-turut. Kondisi perendaman adalah pada suhu $5^{\circ} \mathrm{C}$ dengan waktu selama 1,5 jam dan pengadukan $27 \mathrm{rpm}$, diikuti dengan proses dipping selama 20 jam pada suhu $5^{\circ} \mathrm{C}$

\section{Pengukuran rendemen dan water holding capa- city}

Pengukuran bobot dan penghitungan rendemen dilakukan sebelum perlakuan, setelah perlakuan, dan pada saat setelah es pada produk dicairkan, yaitu setelah proses pembekuan. Proses pelelehan udang beku yang berbentuk blok dilakukan dengan cara mengalirkan air bersih dengan suhu $10-18^{\circ} \mathrm{C}$ disertai dengan penirisan. Bobot yang diukur adalah bobot basah dari udang.

Pengukuran water holding capacity dilakukan dengan metode Hamm (Swatland, 1984) pada saat udang sebelum mengalami perlakuan, sesudah mengalami perlakuan, dan saat produk telah dikemas dalam plastik LDPE. Pertama, sampel udang dan ditimbang sebanyak $\pm 0,5 \mathrm{~g}$. Kemudian, udang diletakkan pada kertas Whatman no.43. Udang ditekan menggunakan beban $5 \mathrm{~kg}$ selama 5 menit. Cetakan yang terbentuk pada kertas Whatman dipindahkan ke kertas milimeter blok. Kemudian dihitung luas area basah dan dinyatakan ke dalam satuan $\mathrm{cm}^{2}$.

$$
\mathrm{mg} \mathrm{H}_{2} \mathrm{O}=\frac{\text { area basah }\left(\mathrm{cm}^{2}\right)}{0,0948}-8,0
$$

dimana, nilai 0,0948 dan 8,0 adalah konstanta metode Hamm (Swatland, 1984). Setelah luas area basah ditemukan, kadar air bebas dihitung dengan menggunakan rumus:

$$
\text { Kadar air bebas }=\frac{\mathrm{mg} \mathrm{H}_{2} \mathrm{O}}{\text { berat sampel }(\mathrm{mg})} \times 100 \%
$$

Setelah kadar air bebas diperoleh, kadar air udang juga harus dihitung menggunakan oven UN55 (Memmert GmbH + Co. KG). Penghitungan dilakukan dengan mengeringkan cawan di oven selama 15 menit dan didinginkan di desikator selama 10 menit, kemudian ditimbang (A). Sejumlah sampel dengan bobot tertentu dimasukkan ke dalam cawan (B). Cawan beserta isinya dikeringkan dalam oven pada suhu $105^{\circ} \mathrm{C}$ selama 16 jam. Cawan kemudian didinginkan di dalam desikator, kemudian ditimbang sehingga diperoleh bobot konstan (C). Kadar air daging basis basah (\%bb) dapat dihitung dengan persamaan berikut:

$$
\text { Kadar air }(\% b b)=\left(\frac{B-(C-A)}{B}\right) \times 100 \%
$$

Sehingga, nilai $\mathrm{WHC}$ diperoleh dengan cara: $\mathrm{WHC}=$ Kadar Air Daging - Kadar Air Bebas.

\section{Pengukuran kadar fosfat: Persiapan sampel}

Cawan dikeringkan di dalam oven UN55 (Memmert $\mathrm{GmbH}+\mathrm{Co}$. $\mathrm{KG}$ ) pada suhu $100^{\circ} \mathrm{C}$ selama 15 menit, lalu didinginkan dalam desikator dan ditim- 
bang (A). Sampel dengan bobot tertentu (B) dimasukkan ke dalam cawan porselen (B), kemudian dibakar di dalam ruang asap sampai tidak mengeluarkan asap lagi. Selanjutnya, dilakukan pengabuan di dalam tanur listrik pada suhu $400-600^{\circ} \mathrm{C}$ selama $4-6$ jam sampai terbentuk abu berwarna putih dan memiliki bobot yang tetap. Abu beserta cawan didinginkan dalam desikator, kemudian ditimbang (C). Kadar abu contoh dapat dihitung dengan persamaan berikut (Matanjun et al., 2009):

$$
\text { Kadar Abu }(\% b b)=\left(\frac{C-A}{B}\right) \times 100 \%
$$

Abu yang dihasilkan diambil sebanyak $0,5 \mathrm{~g}$ untuk analisis kadar $\mathrm{P}_{2} \mathrm{O}_{5}$.

\section{Pengukuran kadar fosfat: Pereaksi dan larutan baku}

Larutan ammonium molibdovanadat dibuat dengan mencampurkan larutan ammonium molibdat $8 \%$ yang dibuat dengan melarutkan $80 \mathrm{~g}$ ammonium tetrahidrat dengan air destilata hingga $1 \mathrm{~L}$, dan larutan ammonium monovanadat $0,4 \%$ yang dibuat dengan melarutkan $4 \mathrm{~g}$ ammonium monovanadat dengan $500 \mathrm{~mL} \mathrm{HClO}_{4}$ p.a (Sigma-Aldrich (Singapura)), kemudian diencerkan dengan air destilata hingga $1 \mathrm{~L}$. Kedua larutan ini dicampurkan dengan perbandingan 1:1. Pencampuran dilakukan pada saat larutan ammonium monovanadat akan digunakan.

Larutan baku $\mathrm{P}_{2} \mathrm{O}_{5}$ dibuat dengan melarutkan kristal kalium dihidrogen fosfat $\left(\mathrm{KH}_{2} \mathrm{PO}_{4}\right)$ (SigmaAldrich (Singapura)) sebanyak 0,9587 g ke dalam labu takar $1 \mathrm{~L}$ menggunakan air destilata dengan terlebih dahulu dikeringkan selama dua jam pada suhu $105^{\circ} \mathrm{C}$.

\section{Pengukuran kadar fosfat: Analisis menggunakan spektrofotometer}

Penentuan fosfat kandungan $\mathrm{P}_{2} \mathrm{O}_{5}$ dalam udang beku menggunakan larutan aquaregia dilakukan dengan beberapa tahapan. Tahap-tahap pengukuran meliputi pembuatan kurva kalibrasi standar $\mathrm{P}_{2} \mathrm{O}_{5}$, penyiapan dan pengukuran sampel. Tahap pembuatan kurva kalibrasi standar $\mathrm{P}_{2} \mathrm{O}_{5}$ dilakukan dengan larutan baku $\mathrm{P}_{2} \mathrm{O}_{5} 0,5 \mathrm{mg} / \mathrm{mL}$ dipipet secara seri sebanyak $1,2,3,4$, dan $5 \mathrm{~mL}$ (masing-masing mengandung 0,$5 ; 1,0 ; 1,5 ; 2,0$ dan $2,5 \mathrm{mg} \mathrm{P}_{2} \mathrm{O}_{5}$ ), yang dimasukkan ke dalam labutakar $100 \mathrm{~mL}$. Kemudian, larutan diencerkan dengan air destilata 50 $\mathrm{mL}$ dan ditambahkan $20 \mathrm{~mL}$ larutan pereaksi ammonium molibdovanadat, kemudian diencerkan kembali dengan air destilata hingga tanda garis dan dilakukan pengocokan (lakukan pengerjaan larutan blanko atau $0 \mathrm{mg} \mathrm{P}_{2} \mathrm{O}_{5}$ ). Larutan dibiarkan selama 10 menit untuk pengembangan warna hingga didapatkan warna konstan. Larutan diukur intensitas warna dengan spektrofotometer UV-VIS (Shimadzu) pada kisaran gelombang 420-440 $\mathrm{nm}$ terhadap larutan blanko beserta larutan standar (Pradhan dan Pokhrel, 2013).

Pengukuran fosfat pada sampel dilakukan dengan menimbang $0,5 \mathrm{~g}$ contoh abu sampel yang ditimbang dan dimasukkan ke dalam gelas piala 100 $\mathrm{mL}$, kemudian ditambahkan larutan aquaregia sebanyak $40 \mathrm{~mL}\left(\mathrm{HCl}-\mathrm{HNO}_{3}\right.$ dengan perbandingan 3:1) dan campuran dipanaskan sehingga didapat volume larutan sebanyak 2-5 mL. Setelah itu campuran dibiarkan hingga dingin. Kemudian larutan diencerkan dengan air destilata dan dimasukan kedalam labu takar $500 \mathrm{~mL}$ dan diencerkan kembali dengan air destilata hingga tanda garis, kemudian dilakukan pengocokan larutan. Diambil $1.0 \mathrm{~mL}$ larutan sampel yang dimasukan ke dalam labu takar $100 \mathrm{~mL}$, yang kemudian diencerkan dengan air destilata $50 \mathrm{~mL}$, dan ditambahkan $20 \mathrm{~mL}$ larutan pereaksi ammonium molibdovanadat. Larutan ini kemudian diencerkan kembali dengan air destilata hingga tanda garis, dan dilakukan pengocokan dengan vortex selama 10 detik. Larutan dibiarkan selama 10 menit untuk pengembangan warna hingga didapatkan warna konstan. Intensitas warna larutan diukur dengan spektrofotometer pada kisaran gelombang 420-440 nm terhadap blanko.

Tabel 1. Atribut uji organoleptik

\begin{tabular}{|c|c|c|c|}
\hline \multirow{2}{*}{ Skala } & \multicolumn{3}{|c|}{ Atribut } \\
\hline & Kenampakan & Tekstur & Rasa \\
\hline 1 & $\begin{array}{l}\text { Warna pudar } \\
\text { keputih-putihan, } \\
\text { sangat kusam, } \\
\text { kotor, noda hitam } \\
\text { banvak }\end{array}$ & $\begin{array}{l}\text { Membubur, } \\
\text { sangat } \\
\text { lembek/lunak } \\
\text { dan berair }\end{array}$ & $\begin{array}{l}\text { Pahit, } \\
\text { sepet, dan } \\
\text { asam }\end{array}$ \\
\hline 2 & $\begin{array}{l}\text { Warna pudar } \\
\text { merah keputihan, } \\
\text { kusam, sedikit } \\
\text { kotor, noda hitam } \\
\text { mulai tumbuh }\end{array}$ & $\begin{array}{l}\text { Kurang } \\
\text { elastis, } \\
\text { lembut/lunak }\end{array}$ & $\begin{array}{l}\text { Hambar } \\
\text { dan sedikit } \\
\text { pahit/sepet }\end{array}$ \\
\hline 3 & $\begin{array}{l}\text { Warna merah } \\
\text { muda pucat, } \\
\text { sedikitcacat, } \\
\text { kusam }\end{array}$ & $\begin{array}{l}\text { Kurang } \\
\text { elastis, } \\
\text { sedikit } \\
\text { rongga, agak } \\
\text { lembek/lunak }\end{array}$ & $\begin{array}{l}\text { Sedikit } \\
\text { manis dan } \\
\text { agak } \\
\text { hambar }\end{array}$ \\
\hline 4 & $\begin{array}{l}\text { Utuh, warna } \\
\text { merah muda, } \\
\text { agak cerah dan } \\
\text { bersih }\end{array}$ & $\begin{array}{l}\text { Elastis, } \\
\text { kompak, } \\
\text { kurang padat }\end{array}$ & $\begin{array}{l}\text { Dominan } \\
\text { asin }\end{array}$ \\
\hline 5 & $\begin{array}{l}\text { Utuh, warna } \\
\text { merah muda, } \\
\text { cerah dan bersih }\end{array}$ & $\begin{array}{l}\text { Elastis, } \\
\text { kompak dan } \\
\text { padat/kenyal }\end{array}$ & Asin-manis \\
\hline
\end{tabular}

\section{Uji organoleptik}

Metode uji organoleptik yang digunakan adalah multisample difference test: rating (Troncoso et al., 2009). Uji ini meliputi rasa, tekstur dan kenampakan. Panelis terlatih yang digunakan adalah sebanyak delapan orang. Skala yang digunakan adalah dari 1 sampai 5 . Nilai yang paling tinggi menandakan nilai yang mempunyai mutu terbaik. Sampel yang digu- 
nakan adalah sampel udang setelah perebusan pada suhu $100^{\circ} \mathrm{C}$ selama 240 detik.

\section{Analisis biaya produksi}

Analisis biaya produksi dilakukan untuk mengevaluasi penurunan biaya bahan dasar (raw material) dengan kombinasi optimum bahan perendam antara garam dan fosfat. Penentuan biaya produksi dari masing-masing perlakuan dilakukan dengan menggunakan asumsi bahwa setiap harinya dilakukan produksi yang menghasilkan $2.000 \mathrm{~kg}$ produk akhir. Menggunakan nilai rendemen dari udang PND ke produk akhir dapat diperoleh jumlah polifosfat, garam, dan sodium bikarbonat yang digunakan beserta jumlah biaya yang harus dikeluarkan. Untuk menentukan jumlah dan ukuran udang head-on (HO) yang akan digunakan pada satu kali produksi, maka persamaan berikut harus digunakan.

Size udang headless $=\mathrm{A} \times \mathrm{B}$

Size udang head-on $=\frac{1000 \times A \times B \times C}{453,6}$

dimana, $\mathrm{A}=$ ukuran produk akhir, $\mathrm{B}=$ rendemen udang dari headless ke produk akhir dan $\mathrm{C}=$ rendemen udang dari head-on ke headless. Untuk menentukan jumlah polifosfat, sodium bikarbonat, dan garam yang dibutuhkan, maka persamaan berikut harus digunakan:

Kebutuhan garam $(\mathrm{kg})=$

2×konsentrasi garam $\times$ bobot PND

Biaya garam $(R p)=1.500 \times$ kebutuhan garam

Kebutuhan polifosfat $(\mathrm{kg})=$

2×konsentrasi polifosfat $\times$ bobot PND

Biaya polifosfat $(R p)=25.366 \times$ kebutuhan polifosfat

Kebutuhan bikarbonat $(\mathrm{kg})=$

2×konsentrasi bikarbonat×bobot PND

Biaya polifosfat $(R p)=23.450 \times$ kebutuhan bikarbonat

Total biaya BTP=

biaya polifosfat+biaya bikarbonat+biaya garam

Total biaya RM dan BTP=

Total biaya BTP+(bobot HO×harga RM)

\section{Rancangan percobaan}

Rancangan percobaan yang digunakan adalah Rancangan Acak Kelompok Faktorial (RAKF), dengan dua faktor yaitu konsentrasi polifosfat dan konsentrasi garam. Faktor konsentrasi polifosfat dibagi menjadi dua taraf yaitu 2 dan 2,5\%, sedangkan faktor konsentrasi garam dibagi menjadi tiga taraf yaitu 0,$5 ; 1$; dan $2 \%$ sehingga kombinasi dua faktor tersebut menghasilkan enam perlakuan di antaranya: $A=$ konsentrasi garam $0,5 \%$ dan konsentrasi polifosfat $2 \%$; $B=$ konsentrasi garam $1 \%$ dan konsentrasi polifosfat $2 \%$; $C=$ konsentrasi garam $2 \%$ dan konsentrasi polifosfat $2 \% ; D=$ konsentrasi garam $0,5 \%$ dan konsentrasi polifosfat 2,5\%; $E=$ konsentrasi garam $1 \%$ dan konsentrasi polifosfat 2,5\%; dan $\mathrm{F}=$ konsentrasi garam $2 \%$ dan konsentrasi polifosfat $2,5 \%$. Berikut adalah model matematis untuk analisis varian faktorial dari RAKF:

$$
Y_{i j k}=\mu+\alpha_{i}+\beta_{j}+(\alpha \beta)_{i j}+\varepsilon_{i j k}
$$

dimana $Y_{i j k}=$ nilai selisih rendemen/WHC yang memperoleh kombinasi perlakuan konsentrasi polifosfat ke- $i$ dan konsentrasi garam ke-j, $\mu=$ rata-rata nilai rendemen/WHC yang sesungguhnya, $\alpha_{i}=$ pengaruh perlakuan konsentrasi polifosfat ke-i, $\beta_{j}=$ pengaruh perlakuan konsentrasi garam ke- $j,(\alpha \beta)_{i j}=$ pengaruh interaksi perlakuan ke-i, dan ke-j, $\varepsilon_{i j k}=$ pengaruh galat perlakuan ke-i dan ke-j pada satuan percobaan ke-k. Dengan model di atas, maka hipotesis awal $\left(\mathrm{H}_{0}\right)$ dan tandingan $\left(\mathrm{H}_{1}\right)$ dapat dirumuskan sebagai:

$\mathrm{H}_{0}=$ Tidak ada pengaruh penambahan kombinasi garam dan fosfat terhadap daya ikat air, rendemen dan penerimaan sensori udang putih beku

$\mathrm{H}_{1}=$ Terdapat pengaruh penambahan kombinasi garam dan fosfat terhadap daya ikat air dan rendemen udang putih beku

Pengolahan data dari parameter daya ikat air, rendemen dan sensori dilakukan dengan ANOVA menggunakan piranti lunak (software) IBM SPSS $\AA^{8}$ dengan uji lanjut Duncan.

\section{HASIL DAN PEMBAHASAN}

\section{Pengaruh konsentrasi polifosfat dan garam ter- hadap rendemen}

Berdasarkan pengujian dengan ulangan sebanyak tiga kali, diperoleh hasil bahwa perbedaan konsentrasi fosfat dan garam menghasilkan selisih rendemen antara perlakuan dan kontrol yang berbeda. Hasil analisis statistik menunjukkan perbedaan konsentrasi polifosfat dan garam menghasilkan perbedaan yang nyata pada selisih rendemen yang diperoleh pada taraf nyata $95 \%$. Hal ini ditunjukkan dari niai signifikansi $(\alpha)<0,05$. Namun, interaksi antara kedua faktor yaitu, konsentrasi garam dan polifosfat tidak menunjukkan pengaruh yang signifikan pada respon selisih rendemen. Berdasarkan uji lanjut 
Duncan, konsentrasi garam antara 1 dan 2\% tidak memberikan perbedaan yang nyata. Walaupun begitu, pemilihan konsentrasi garam $1 \%$ tetap lebih menguntungkan karena dengan konsentrasi tersebut selisih yang dihasilkan lebih besar dan berada pada subset yang sama dengan perlakuan yang memiliki konsentrasi garam $2 \%$. Perbedaan dari selisih rendemen masing-masing perlakuan dengan control dapat dilihat pada Gambar 1.

Penggunaan data selisih rendemen perlakuan dengan kontrol dilakukan karena ketidakmungkinan untuk melakukan pengujian semua perlakuan pada hari yang sama dan sulitnya memperoleh bahan baku dengan kualitas dan kesegaran yang sama pada hari yang berbeda-beda. Berdasarkan Gambar 1, perlakuan $\mathrm{E}(2,5 \%$ polifosfat dan $1 \%$ garam $)$ memberikan selisih rendemen dengan kontrol yang paling besar yaitu sebesar $4,31 \pm 0,11 \%$ sedangkan perlakuan A ( $2 \%$ polifosfat dan $0,5 \%$ garam) memberikan selisih rendemen dengan kontrol yang paling kecil, yaitu $-2,71 \pm 2,08 \%$.

Peningkatan rendemen melalui penambahan fosfat dan garam terjadi akibat dari adanya peningkatan kekuatan ionik yang menyebabkan terjadinya perenggangan kompleks aktomiosin (Paul et al., 2011). Perenggangan aktomiosin menjadi aktin dan miosin akan meningkatkan kelarutan miosin. Selanjutnya, peningkatkan kekuatan ionik akan menyebabkan gaya tolak menolak pada molekul protein, dan mempermudah proses difusi air ke dalam daging. Pengikatan air pada otot miofibrillar terjadi karena adanya interaksi antara protein dan air melalui ikatan hidrogen, yakni antara molekul air dengan sisi protein hidrofilik yang bersifat polar.

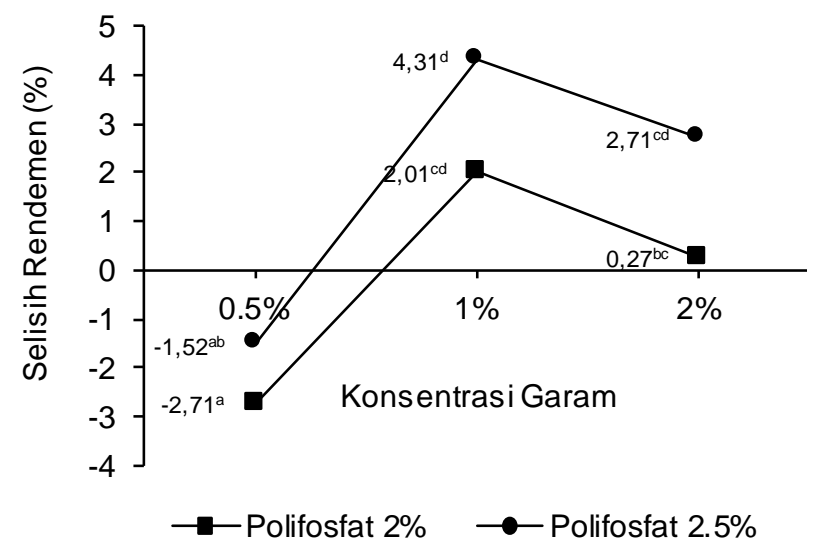

Gambar 1. Pengaruh konsentrasi polifosfat dan garam terhadap selisih rendemen perlakuan dan kontrol

\section{Pengaruh konsentrasi polifosfat dan garam terhadap daya ikat air (water holding capacity/ WHC)}

Pengunaan polifosfat pada industri komoditas perikanan selalu bertujuan meningkatkan daya ikat air (WHC). Selama proses pre-rigor, penumpukan asam laktat di jaringan otot yang terjadi akibat tidak adanya oksigen akan menyebabkan turunnya $\mathrm{pH}$ jaringan. Pada Gambar 2, ketika pH jaringan sudah mencapai titik isoelektrik dari protein $/ \operatorname{miosin}(\mathrm{pl}=$ $5,4 / 5,5)$, membuat net charge dari protein menjadi nol yang berarti muatan positif dan negatif pada protein saling tarik menarik, sehingga dapat menyebabkan penurunan kemampuan protein dalam mengikat air (Carneiro et al., 2012b).

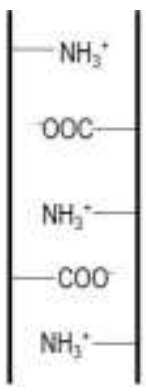

$\mathrm{pH} 5,5$

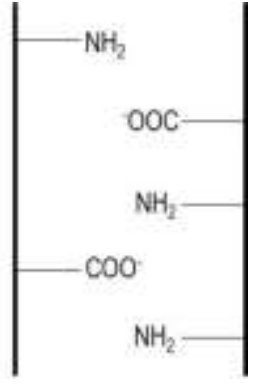

$\mathrm{pH} 7,0$

\section{Gambar 2. Pengaruh pH terhadap struktur protein}

WHC dapat ditingkatkan dengan adanya fosfat, karena keberadaan fosfat di dalam struktur daging dapat merenggangkan kompleks aktomiosin (Paul et al., 2011). Kompleks aktomiosin yang renggang akan memberikan ruang di antara filamen otot sehingga larutan/air dapat masuk dengan mudah (Lopkulkiaert et al., 2009). Selain itu, WHC dapat ditingkatkan melalui kenaikan $\mathrm{pH}$ otot yang menyebabkan meningkatnya jumlah muatan negatif pada otot udang sehingga munculnya gaya tolak menolak pada otot udang (Wachirasiri et al., 2013). Sifat fosfat yang bersifat buffer yang baik dapat meningkatkan $\mathrm{pH}$ daging jauh dari titik isoelektrik protein sehingga gaya elektrostatis pada aktin dan miosin yang muncul akan menjadi lebih besar. Gaya tolak menolak pada kompleks aktomiosin akan memberikan ruang yang lebih untuk proses masuknya air ke dalam otot sehingga WHC dari udang dapat meningkat (Gambar 2). Kemudian, pengkelatan ion $\mathrm{Ca}^{2+}$, $\mathrm{Fe}^{2+}, \mathrm{Fe}^{3+}, \mathrm{Mg}^{2+}$, dan lain-lain dapat terjadi dengan fosfat pada daging (Lopkulkiaert et al., 2009). Proses pengikatan ion logam (cross-bridge pada kompleks aktomiosin) yang dilakukan oleh fosfat sehingga membentuk kompleks dapat menyebabkan terjadinya perenggangan aktin dan miosin setelah peristiwa rigor mortis. Selain meningkatkan keempukan daging, pengkelatan juga mampu mengurangi bahaya ketengikan oksidatif (Gonçalves dan Ribeiro, 2008).

Penambahan garam pada udang harus disertai dengan penambahan fosfat. Walaupun garam mampu meningkatkan derajat pembengkakan protein, namun garam apabila tidak ditambahkan dengan 
fosfat tidak mampu melarutkan protein sebanyak campuran fosfat dan garam (Jantokoson et al., 2013). Maka dari itu campuran fosfat dan garam menghasilkan interaksi yang berperan sangat penting untuk melarutkan protein pada otot dan juga meningkatkan retensi air pada otot.

Berdasarkan hasil analisis statistik, interaksi antara konsentrasi garam dan polifosfat memberikan pengaruh yang nyata terhadap respon selisih daya ikat air. Selain itu, faktor konsentrasi garam dan polifosfat juga memberikan pengaruh yang nyata $(P<0,05)$ terhadap respon selisih daya ikat air. Berdasarkan uji lanjut Duncan, konsentrasi garam memberikan pengaruh secara signifikan terhadap daya ikat air. Hal ini dibuktikan dari ketiga subset yang berbeda yang dimiliki ketiga konsentrasi garam. Perlakuan E (2,5\% polifosfat dan $1 \%$ garam) memberikan selisih daya ikat air dengan kontrol yang paling besar yaitu sebesar $1,39 \pm 0,08 \%$ sedangkan perlakuan $C$ ( $2 \%$ polifosfat dan $2 \%$ garam) memberikan pengaruh negative terhadap daya ikat air, jika dibandingkan dengan kontrol $(-1,27 \pm 0,05 \%)$. Dengan demikian, perlakuan $\mathrm{E}$ merupakan kondisi kombinasi konsentrasi optimum dari fosfat dan garam yang diperlukan dalam perendaman udang (Gambar 3).

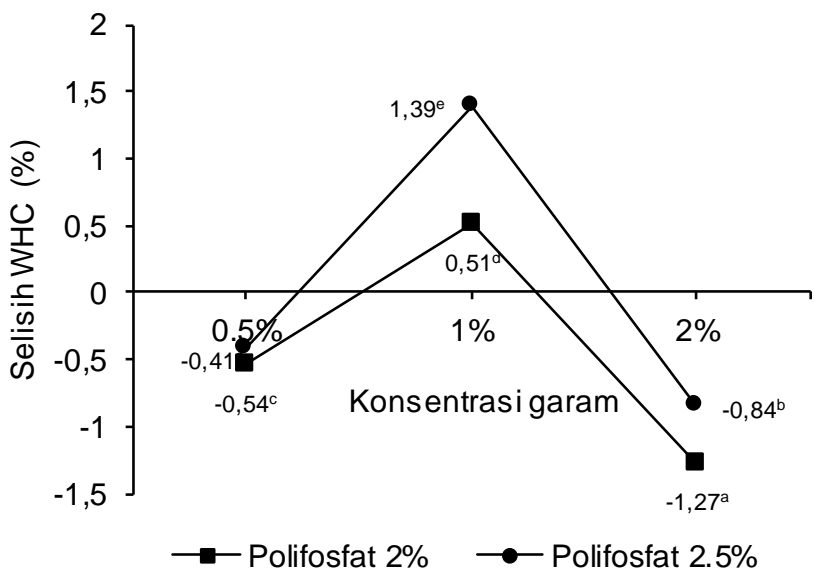

Gambar 3. Pengaruh konsentrasi polifosfat dan garam terhadap selisih daya ikat air perlakuan dan kontrol

Peningkatan WHC maupun rendemen melalui penambahan fosfat pada filet ikan kutum juga dilaporkan oleh Etemadian et al. (2012). Kombinasi sodium tripolifosfat (STPP) dan sodium pirofosfat (PP) dapat menaikkan WHC dengan adanya efek kompleks aktomiosin sehingga protein daging mampu untuk memiliki ruang dan interaksi yang cukup untuk mengikat air (Carneiro et al., 2012b). Kombinasi penambahan polifosfat dengan natrium klorida $(\mathrm{NaCl})$ juga telah dilaporkan bersifat sinergis pada peningkatan WHC filet ikan kod (Johnsen et al., 2009). Bukan hanya pada filet mentah, namun setelah proses pemasakan, kombinasi polifosfat dan garam mampu untuk tetap meningkatkan WHC, yakni sebesar $41 \%$ dibandingkan dengan kontrol (Johnsen et al., 2009). Umumnya, ion $\mathrm{Cl}$ - dapat berikatan dengan filamen untuk meningkatkan muatan negatif yang menyebabkan munculnya gaya elektrostatik yang dapat menyebabkan meningkatnya ruang antar filamen (Damez dan Clerjon, 2008). Namun, pada konsentrasi yang terlalu tinggi, kecenderungan $\mathrm{NaCl}$ untuk menarik air ke dalam kompleks aktomiosin menurun (peristiwa salting-out) (Nguyen et al., 2011).

\section{Hasil uji organoleptik}

Hasil uji organoleptik dapat dilihat pada Tabel 2. Berdasarkan hasil uji ANOVA, tidak ditemukan perbedaan yang nyata pada tekstur udang antara semua perlakuan. Pada karakteristik penampakan dan rasa terdapat pengaruh nyata penambahan kombinasi garam dan fosfat saat perendaman udang putih. Perbedaan yang nyata ini diindikasikan oleh nilai signifikansi (a) lebih besar dari 0,05 diantara perlakuan. Namun, setelah dilakukan uji lanjut Duncan pada kedua karakteristik, tidak dapat perbedaan nyata antara perlakuan $\mathrm{E}$ dengan kontrol karena kedua perlakuan berada pada subset yang sama. Keenam perlakuan (A-F) dan kontrol $(K)$ menunjukkan karakteristik yang serupa yaitu dengan penampakan utuh, warna merah muda, agak cerah dan bersih dengan rasa dominan asin dan tekstur elastis, kompak, kurang padat. Dengan demikian, penambahan kombinasi fosfat dan garam pada perlakuan $\mathrm{E}$ tidak memengaruhi skor penerimaan pro-duk udang beku.

Tabel 2. Hasil uji organoleptik

\begin{tabular}{cccc}
\hline \multirow{2}{*}{ Perlakuan } & \multicolumn{3}{c}{ Nilai Rata-rata } \\
\cline { 2 - 4 } & Penampakan & Tekstur & Rasa \\
\hline A & $4,58 \pm 0,26^{\circ}$ & $4.54 \pm 0,33^{\mathrm{a}}$ & $3.71 \pm 0,29^{\mathrm{a}}$ \\
B & $4,08 \pm 0,13^{\mathrm{a}}$ & $4,38 \pm 0,13^{\mathrm{a}}$ & $4.38 \pm 0,13^{\mathrm{D}}$ \\
C & $4,21 \pm 0,26^{\text {ao }}$ & $4,29 \pm 0,26^{\mathrm{a}}$ & $3,63 \pm 0,76^{\mathrm{a}}$ \\
D & $4,38 \pm 0,33^{\text {ao }}$ & $4,54 \pm 0,26^{\mathrm{a}}$ & $3,88 \pm 0,38^{\mathrm{ad}}$ \\
E & $4,29 \pm 0,07^{\text {a }}$ & $4,50 \pm 0,13^{\mathrm{a}}$ & $4,33 \pm 0,07^{\mathrm{D}}$ \\
F & $4,21 \pm 0,07^{\text {ao }}$ & $4,33 \pm 0,07^{\mathrm{a}}$ & $3,96 \pm 0,19^{\text {ao }}$ \\
K & $4,00 \pm 0,13^{\mathrm{a}}$ & $4,13 \pm 0,33^{\mathrm{a}}$ & $3,88 \pm 0,33^{\text {ao }}$
\end{tabular}

Keterangan: Huruf yang berbeda menandakan subsetberbeda yang menunjukkan perbedaan yang nyata pada $\alpha=0,05$

\section{Konsentrasi fosfat $\left(\mathrm{P}_{2} \mathrm{O}_{5}\right)$ pada produk akhir}

Penggunaan polifosfat dalam industri udang be$\mathrm{ku}$ harus merujuk pada peraturan yang ada, baik nasional maupun internasional. Menurut Codex, batas residu fosfat pada produk udang beku tidak boleh melebihi $1,0 \%$ dalam bentuk $\mathrm{P}_{2} \mathrm{O}_{5}$ (CAC, 1995). Peraturan serupa juga diatur oleh Kementrian Kesehatan $\mathrm{RI}$ melalui PERMENKES 722/MENKES/PER/IXI 88 yang menyatakan bahwa batas residu fosfat pada produk udang beku tidak boleh melebihi $0,5 \%$. Pengukuran fosfat dilakukan secara triplo untuk perlakuan E (kondisi optimum) dengan kontrol. Melalui 
hasil pengujian (Tabel 3), diperoleh hasil residu fosfat pada produk dengan perlakuan $E$ dan kontrol memiliki residu fosfat yang hamper sama sekitar 0,27-0,28\%, dan nilai ini berada di bawah batas maksimal yang ditetapkan oleh Codex maupun $\mathrm{Ke}$ menterian Kesehatan RI. Oleh sebab itu, dapat disimpulkan bahwa produk hasil perlakuan $\mathrm{E}$ memenuhi standar yang berlaku baik nasional maupun internasional.

\section{Biaya produksi}

Keuntungan dari produksi dihitung berdasarkan rendemen total yang diperoleh. Melalui rendemen total, jumlah bahan kimia dan bahan baku yang digunakan dapat diperkirakan. Analisis biaya produksi dilakukan dengan menggunakan perlakuan $E(2,5 \%$ polifosfat dan $1 \%$ garam) dan kontrol dengan pertimbangan bahwa perlakuan $\mathrm{E}$ menghasilkan selisih rendemen dan WHC yang terbesar, juga karakteristik sensori yang tidak berbeda nyata dengan produk awal yaitu kontrol. Walaupun perlakuan B menggunakan bahan baku yang lebih sedikit dibandingkan dengan perlakuan $E$, pemilihan perlakuan $E$ sebagai perlakuan terbaik dikarenakan nilai karakteristik penampakan yang lebih tinggi pada uji organoleptik. Analisis dilakukan dengan asumsi bahwa jumlah total produk jadi (finished goods) sebanyak 2 ton/hari, harga pembelian bahan baku sebesar Rp 71.200/kg untuk perlakuan E dan Rp 71.500/kg untuk kontrol. Adanya perbedaan harga disebabkan oleh perbedaan rendemen yang dihasilkan oleh kedua perlakuan.
Pada Tabel 4 disajikan rincian dari analisis biaya produksi perlakuan $\mathrm{E}$ dan kontrol.

Dengan basis produksi $2.000 \mathrm{~kg} /$ hari, produksi udang beku yang mengunakan perlakuan $E$ membutuhkan 2.963,76 kg bahan baku, sementara kondisi produksi kontrol membutuhkan lebih banyak bahan baku yakni sebesar $3.031,14 \mathrm{~kg}$. Walaupun perlakuan $\mathrm{E}$ membutuhkan biaya bahan kimia yang lebih besar (Rp 4.437,891/2.000 kg produk jadi) dibandingkan dengan perlakuan kontrol ( $R p$ 3.312,386/ $2.000 \mathrm{~kg}$ produk jadi), namun total biaya yang dikeluarkan untuk perlakuan $\mathrm{E}$ lebih rendah karena perbedaan jumlah bahan baku yang dibutuhkan, dan perbedaan harga dari bahan baku perlakuan $E$ dan kontrol. Penggunaan perlakuan $\mathrm{E}$ dapat menghemat biaya produksi sebesar $\mathrm{Rp} 4.580,900 / 2.000 \mathrm{~kg}$ produk jadi atau sebesar Rp 2.290,00/kg produk jadi.

\section{KESIMPULAN}

Pada penelitian ini didapatkan hasil yang menunjukkan bahwa perlakuan perendaman kombinasi garam dan fosfat memiliki pengaruh atas rendemen dan WHC dari produk udang putih beku (tolak $\mathrm{H}_{0}$ ). Peningkatan rendemen dan WHC udang putih beku (L. vannamei) melalui penambahan fosfat dan garam terjadi akibat adanya peningkatan kekuatan ionik yang menyebabkan terjadinya perenggangan kompleks aktomiosin pada struktur daging udang putih.

Tabel 3. Konsentrasi fosfat pada udang beku

\begin{tabular}{lcccc}
\hline \multicolumn{1}{c}{ Kondisi } & Ulangan & $\begin{array}{c}\text { Konsentrasi Fosfat } \\
(\%)\end{array}$ & $\begin{array}{c}\text { Batas Residu dari CAC } \\
(1995)\end{array}$ & $\begin{array}{c}\text { Batas Residu dari PERMENKES } \\
722 / \text { MENKES/PER/IX/88 }\end{array}$ \\
\hline Kontrol & $3 \mathrm{X}$ & $0,28 \pm 0,04$ & $1,0 \%$ & $0,5 \%$ \\
Perlakuan E & $3 \mathrm{X}$ & $0,27 \pm 0,09$ & $1,0 \%$ & $0,5 \%$ \\
\hline
\end{tabular}

Tabel 4. Analisis biaya produksi

\begin{tabular}{|c|c|c|}
\hline \multirow{2}{*}{ Kategori } & \multicolumn{2}{|c|}{ Kondisi Perendaman } \\
\hline & Perlakuan E & Kontrol \\
\hline Asumsi FG=2000 kg/hari & 2,000 & 2,000 \\
\hline Yield (PND to FG) & $121,92 \pm 2,27 \%$ & $119,21 \pm 2,12 \%$ \\
\hline Bobot PND (kg) & $1,640.44$ & $1,677.74$ \\
\hline Yield (HL to Peel) & $82 \%$ & $82 \%$ \\
\hline Bobot HL (kg) & $2,000.54$ & $2,046.02$ \\
\hline Yield ( $\mathrm{HO}$ to $\mathrm{HL})$ & $67.50 \%$ & $67.50 \%$ \\
\hline Bobot $\mathrm{HO}(\mathrm{kg})$ & $2,963.76$ & $3,031.14$ \\
\hline Yield (HL to FG) & $99.97 \%$ & $98 \%$ \\
\hline Kebutuhan garam/2000 kg FG (kg) & 32.81 & 67.11 \\
\hline Biaya kebutuhan garam $(1.500 / \mathrm{kg})$ & Rp 49.213 & Rp 100.664 \\
\hline Kebutuhan MTR 80-P/2000 kg FG (kg) & 82.02 & 33.55 \\
\hline Biaya kebutuhan MTR $80-P(25.366 / \mathrm{kg})$ & Rp $2,080.574$ & Rp 851.149 \\
\hline Kebutuhan MTR 79-N/2000 kg FG (kg) & 98.43 & 100.66 \\
\hline Biaya kebutuhan MTR 79-N (23.450/kg) & Rp 2,308,104 & Rp 2,360,573 \\
\hline Total biaya bahan kimia/2000 kg FG & $\mathrm{Rp} 4,437,891$ & Rp3,312,386 \\
\hline Total biaya RM dan bahan kimia/2000 kg FG & Rp 215,457,887 & Rp 220.038.788 \\
\hline Total biaya RM dan bahan kimia/kg FG & $\operatorname{Rp} 107,729$ & Rp 110,019 \\
\hline Saving cost RM dan bahan kimia/2000 kg FG & $\operatorname{Rp} 4,58$ & \\
\hline Saving cost RM dan bahan kimia/kg FG & $\mathrm{Rp} 2$, & \\
\hline
\end{tabular}


Konsentrasi optimum dari polifosfat dan ga-ram yang didapatkan adalah pada perlakuan $\mathrm{E}(2,5 \%$ polifosfat MTR $80-\mathrm{P}$ dan $1 \% \mathrm{NaCl}$ ) dengan selisih kenaikan rendemen dan WHC dengan kontrol $(\mathrm{K})$ sebesar 4,31 dan 1,39\%. Dengan uji lanjut Dun-can, penambahan kombinasi fosfat dan garam pada perlakuan $\mathrm{E}$ tidak memengaruhi skor penerimaan produk udang beku jika dibandingkan dengan kontrol. Proses perendaman dengan kondisi perlakuan ini dapat menghemat biaya produksi $\mathrm{Rp} 4.580,900 /$ $2.000 \mathrm{~kg}_{\text {produk jadi }}$ atau sebesar $\mathrm{Rp} 2.290,00 / \mathrm{kg}_{\text {produk }}$ jadi. Hasil analisis residu fosfat pada produk akhir $\left(\mathrm{P}_{2} \mathrm{O}_{5}\right)$ pada perlakuan $\mathrm{E}$ menunjukkan bahwa tidak ada perbedaan signifikan dengan kontrol, dimana nilai kedua residu (baik perlakuan $\mathrm{E}$ dan kontrol) berada di bawah standar Codex dan Peraturan Kementrian Kesehatan RI.

\section{DAFTAR PUSTAKA}

[BSN] Badan Standardisasi Nasional. 2014. SNI-012705-2014: Udang Beku. 2-3. Badan Stadardisasi Nasional (BSN), Jakarta.

Carneiro $C D$, Mársico $E T$, Ribeiro RD, Júnior $C D$, Álvares TS, Oliveira De Jesus EF. 2012a. Quality attributes in shrimp treated with polyphosphate after thawing and cooking: A study using physicochemical analytical methods and lowfield ${ }^{1} \mathrm{H}$ NMR. J Food Process Eng 36: 492-499. DOI: $10.1111 /$ jpe. 12011

Carneiro $C D$, Mársico $E T$, Ribeiro RD, Júnior $C D$, Álvares TS, Oliveira De Jesus EF. 2012b. Studies of the effect of sodium tripolyphosphate on frozen shrimp by physicochemical analytical methods and low field nuclear magnetic resonance (LF ${ }^{1} \mathrm{H}$ NMR). LWT-Food Sci Technol 50: 401-407. DOI: 10.1016/j.Iwt.2012.09.009.

Chen K, Lia E, Xu C, Wang X, Lin H, Qin JC, Chen L. 2015. Evaluation of different lipid sources in diet of pacific white shrimp Litopenaeus vannamei at low salinity. Aquaculture Reports 2: 163168. DOI: 10.1016/j.aqrep.2015.10.003.

[CAC] Codex Alimentarius Commission. 1995. Report of the twenty-first session of the codex committee on fish and fishery products. http:// www.fao.org/docrep/meeting/005/v7950e/v7950 e00.htm [02 Maret 2018].

Damez JL, Clerjon S. 2008. Meat quality assessment using biophysical methods related to meat structure. Meat Sci 80: 132-149. DOI: 10.1016/j. meatsci.2008.05.039.

Etemadian Y, Shabanpour B, Mahoonak AS, Shabani A. 2012. Combination effect of phosphate and vacuum packaging on quality parameters of Rutilus frisii kutum fillets in ice. Food Res Int 45: 9-16. DOI: 10.1016/j.foodres.2011.09.026.

Gonçalves AA, Ribeiro JLD. 2009. Effects of phosphate treatment on quality of red shrimp (Pleoticus muelleri) processed with cryomechanical freezing. LWT-Food Sci Technol 42: 14351438. DOI: 10.1016/j.Iwt.2009.03.016.

Hughes JM, Oiseth SK, Purslow PP, Warner RD. 2014. A structural approach to understanding the interactions between colour, water-holding capacity and tenderness. Meat Science 98: 520-532. DOI: 10.1016/j.meatsci.2014.05.022.

Jantakoson T, Thavaroj W, Konno K. 2013. Myosin and actin denaturation in frozen stored kuruma prawn Marsupenaeus japonicus myofibrils. Fisheries Sci 79: 341-347. DOI: 10.1007/s1256 2-012-0589-y.

Johnsen SO, Jørgensen KB, Birkeland S, Skipnes D, Skåra T. 2009. Effects of phosphates and salt in ground raw and cooked farmed cod $(\mathrm{Ga}$ dus morhua) muscle studied by the water holding capacity (WHC), and supported by ${ }^{31}$ P-NMR measurements. J Food Sci 74: 211-220. DOI: 10.1111/j.1750-3841.2009.01086.x.

Kementerian Kelautan dan Perikanan. 2015. Kelautan dan Perikanan dalam Angka Tahun 2015. http://sidatik.kkp.go.id/files/src/b74413c54e10e d63e28e4ae5cbdf6fa5.pdf [02 Maret 2018]

Lopkulkiaert W, Prapatsornwattana K, Rungsardthong V. 2009. Effects of sodium bicarbonate containing traces of citric acid in combination with sodium chloride on yield and some properties of white shrimp (Penaeus vannamei) frozen by shelf freezing, air-blast and cryogenic freezing. LWT-Food Sci Technol 42: 768-776. DOI: 10.1016/j.Iwt.2008.09.019.

Matanjun P, Mohamed S, Mustapha NM, Muhammad K. 2009. Nutrient content of tropical edible seaweeds, Eucheuma cottonii, Caulerpa lentillifera and Sargassum polycystum. J Appl Phycol 21: 75-80. DOl: 10.1007/s10811-008-9326-4.

Nguyen MV, Thorarinsdottir KA, Gudmundsdottir A, Thorkelsson G, Arason S. 2011. The effects of salt concentration on conformational changes in cod (Gadus morhua) proteins during brine salting. Food Chem 125: 1013-1019. DOl: 10.1016/ j.foodchem.2010.09.109

Nirmal NP, Benjakul S. 2010. Effect of catechin and ferulic acid on melanosis and quality of Pacific white shrimp subjected to prior freeze-thawing during refrigerated storage. Food Control 21: 1263-1271. DOI: 10.1016/j.foodcont.2010.02.0 15. 
Okpala COR. 2015. The physicochemical changes of farm-raised pacific white shrimp (Litopenaeus vannamei) as influenced by iced storage. Food Nutr Sci 6: 906-922. DOI: 10.4236/fns.2015.610 095.

Paul S, Reza MS, Mandal AS, Ahmed IM, Khan MN, Islam MN, Kamal M. 2011. Effect of sodium tri polyphosphate (STPP) and foreign materials on the quality of giant freshwater prawn (Macrobrachium rosenbergii) under ice storage condition. Food Nutr Sci 3: 34-39. DOI: 10.4236/fns.2012. 31007.

Pradhan S, Pokhrel MR. 2013. Spectrophotometric determination of phosphate in sugarcane juice, fertilizer, detergent and water samples by molybdenum blue method. Sci World 11: 58-62. DOI: $10.3126 /$ sw.v11111.9139.

Puga-lopez D, Ponce-palafox JT, Barba-quintero G, Torres-herrera MR, Romero-beltran E, Arredondo-figueroa JL, Gomez MG. 2013. Physicochemical, proximate composition, microbiological and sensory analysis of farmed and wild harvested white shrimp Litopenaeus vannamei (Boone, 1931) tissues. Curr Res J Biol Sci 5: 130-135. DOI: 10.19026/crjbs.5.5454.

Soñanez-Organis JG, Racotta IS, Plascencia Y. 2010. Silencing of the hypoxia inducible factor 1 -HIF-1- obliterates the effects of hypoxia on glucose and lactate concentrations in a tissuespecific manner in the shrimp Litopenaeus vannamei. J Exp Mar Biol Ecol 393: 51-58. DOI: 10.1016/j.jembe.2010.06.031.

Sriket C, Benjakul S, Visessanguan W. 2010. Postmortem changes of muscle from fresh water prawn (Macrobrachium rosenbergii) as influenced by spawning stages. LWT-Food Sci
Technol 43: 608-616. DOI: 10.1016/j.Iwt.2009. 10.010

Swatland HJ. 1984. Structure and Development of Meat Animals. 80-85. Prentice-Hall Inc, Englewood Cliffs, New Jersey.

Thepnuan R, Benjakul S, Visessanguan W. 2009. Effect of pyrophosphate and 4-hexylresorcinol pretreatment on quality of refrigerated white shrimp (Litopenaeus vannamei) kept under modified atmosphere packaging. J Food Sci 73: 124-133. DOI: 10.1111/j.1750-3841.2008.006 74. $x$.

Troncoso E, PedreschiF, Zúñiga RN. 2009. Comparative study of physical and sensory properties of pre-treated potato slices during vacuum and atmospheric frying. LWT-Food Sci Technol 42: 187-195. DOI: 10.1016/j.Iwt.2008.05.013.

Tsironi T, Dermesonlouoglou E, Giannakourou M, Taoukis P. 2009. Shelf life modelling of frozen shrimp at variable temperature conditions. LWT-Food Sci Technol 42: 664-671. DOI: 10.10 16/j.Iwt.2008.07.010.

Wachirasiri K, Wanlapa S, Uttapap D, Rungsardthong V. 2016. Use of amino acids as a phosphate alternative and their effects on quality of frozen white shrimps (Penaeus vanamei). LWTFood Sci Technol 69: 303-311. DOI: 10.1016/j. Iwt.2016.01.065.

Zhou S, Sheen S, Pang Y, Liu L, Yam KL. 2015. Modeling the impact of vapor thymol concentration, temperature, and modified atmosphere condition on growth behavior of Salmonella on raw shrimp. J Food Protect 78: 293-301. DOI: 10. 4315/0362-028X.JFP-14-264. 